\title{
Pengetahuan dan Perspektif Mahasiswa tentang Penuaan dan Keadaan Tua
}

\author{
Patrick, Zita Arieselia, Elisabeth Rukmini \\ Fakultas Kedokteran Universitas Katolik Indonesia Atma Jaya Jakarta
}

\begin{abstract}
Abstrak
Perspektif akan penuaan dan keadaan tua yang negatif akan memudar bila sejak muda ditanamkan pandangan positif. Penelitian ini bertujuan membandingkan pengetahuan dan mencari korelasi antara pengetahuan dan perspektif mahasiswa Fakultas Kedokteran (FK) dan Teknobiologi (FTb) mengenai penuaan dan keadaan tua. Penelitian ini merupakan studi analitik komparatif dan korelatif dengan metode potong lintang. Penelitian dilakukan di FTb dan FK Unika Atma Jaya periode Januari-Mei 2013. Pengetahuan mengenai penuaan dan keadaan tua diukur dengan Facts about Aging Quiz 1 (FAQ 1). Perspektif terhadap penuaan dan kondisi tua diukur dengan Anxiety about Aging Scale (AAS) dan Aging Semantic Differential (ASD). Sampel sebanyak masing-masing 45 mahasiswa FK dan FTb. Data FAQ 1 memperlihatkan pengetahuan mahasiswa FK dan FTb mengenai penuaan dan keadaan tua kurang baik serta tidak ada perbedaan bermakna $(\mathrm{p}=0,199)$. Data AAS memperlihatkan kecenderungan responden tidak takut terhadap lansia, tidak khawatir dengan keadaan fisiologisnya, kurang memperhatikan penampilan fisik, dan tidak takut kehilangan. Data ASD menunjukkan kecenderungan responden merasa lansia akan lebih berguna, tidak bergantung pada orang lain, dan mampu menerima diri sendiri. Uji korelasi FAQ 1 dengan AAS dan ASD tidak menunjukkan hubungan sehingga dapat disimpulkan tidak ada hubungan pengetahuan dengan perspektif terhadap penuaan dan keadaan tua. [MKB. 2014;46(4):209-15]
\end{abstract}

Kata kunci: Keadaan tua, mahasiswa, penuaan

\section{Students' Knowledge and Perspectives on Aging and Aged Condition}

\begin{abstract}
The negative perspectives on aged and aging will be diminished if positive perspectives on aged condition and aging have been introduced in young age. This study aimed to compare and test the relationship between knowledge and perspective toward aged condition and aging among medical and biotechnology students. This study was a comparative analytical and correlative study with a cross-sectional method in the period of January to May 2013 conducted at the School of Biotechnology and the School of Medicine Atma Jaya Catholic University of Indonesia. Knowledge towards aged condition and aging was measured using the Facts about Aging Quiz 1 (FAQ 1). Perspective towards aged condition and aging was measured using the Anxiety about Aging Scale (AAS) and the Aging Semantic Differential (ASD). There were 45 students from each school.. Knowledge about aged condition and aging of the medical and biotechnology students was quite low. There were no significant differences $(p=0.199)$ between the two groups. The AAS data showed that respondents did not have any fear of old people. They were also not really concern about physiological and physical appearances and were not afraid of lost. The ASD data showed that they tended to have positive views: the elderly people are useful, independent, and able to accept their condition. The correlation tests between FAQ 1-AAS and FAQ 1-ASD showed no correlation. In conclusion, there is no relationship between knowledge and perspective towards aged condition and aging. [MKB. 2014;46(4):209-15]
\end{abstract}

Key words: Aged, aging, students

Korespondensi: Patrick, dr., Fakultas Kedokteran Universitas Katolik Indonesia Atma Jaya Jakarta, Jalan Pluit Raya 2, Jakarta 14440, Tel. 021-6693168,e-mail valentinuspatrick@hotmail.com 


\section{Pendahuluan}

Penuaan merupakan proses alamiah yang ditandai dengan penurunan kondisi fisik maupun mental. Batasan usia tua menurut WHO adalah 60 tahun ke atas. Data statistik dunia menunjukkan pada tahun 1990 terdapat kurang lebih setengah miliar penduduk berusia di atas 60 tahun (lanjut usia, lansia) dan 50 juta di antaranya sudah mencapai usia 80 tahun. ${ }^{1}$ Eropa dan Amerika merupakan negara dengan populasi lansia paling banyak, sedangkan di Asia pertumbuhan jumlah lansia terbanyak di Taiwan. Pada tahun 2010, persebaran lansia di Indonesia merata hampir di seluruh provinsi dengan persentase $7,58 \%$. $^{2}$ Persentase lansia di Indonesia diproyeksikan menjadi 11,1\% pada tahun 2020 dan $13,1 \%$ pada tahun $2025 .^{3}$

Jumlah lansia di dunia yang terus meningkat dan kekhawatiran akan menjadi tua akibat dari gambaran keadaan tua yang kurang nyaman akan menagkibatkan muncul permasalahan pada lansia antara lain gangguan kesehatan fisik dan mental. Persepsi yang negatif tentang penuaan dan keadaan tua dapat dicegah bila sejak muda ditanamkan bahwa efek penuaan dan keadaan tua dapat diminimalisasi dengan sikap preventif dan menerima keadaan itu. Menurut Allan dan Johnson, ${ }^{4}$ pengetahuan mengenai penuaan dan keadaan tua berhubungan dengan perspektif tentang penuaan dan keadaan tua. Pada penelitian ini dilakukan hal serupa, peneliti mengambil sampel mahasiswa Fakultas Kedokteran (FK) dan Fakultas Teknobiologi (FTb) Universitas Katolik Indonesia Atma Jaya (UAJ). Pada penelitian ini, mahasiswa FTb dianggap sebagai kelompok pembanding, karena mahasiswa FTb tidak mendapatkan materi kuliah mengenai geriatri dan gerontologi, sedangkan mahasiswa FK mendapatkan materi tersebut.

Tujuan penelitian ini adalah untuk mencari kemungkinan terdapat perbedaan pengetahuan dengan perspektif mengenai penuaan dan keadaan tua antara mahasiswa FK dan mahasiswa FTb; selain itu akan diselidiki hubungan pengetahuan dengan perspektif mengenai penuaan dan juga keadaan tua mahasiswa FK dengan mahasiswa FTb. Hipotesis pada penelitian ini, mahasiswa FK mempunyai pengetahuan mengenai penuaan dan keadaan tua yang lebih baik daripada mahasiswa FTb.

Hasil penelitian ini dapat bermanfaat untuk upaya pencegahan perspektif negatif terhadap penuaan dan keadaan tua. Manfaat penelitian juga diharapkan mampu membantu penentuan suatu intervensi, seperti cara penyampaian materi penuaan dan keadaan tua yang efektif sehingga dapat membentuk perspektif yang baik terhadap penuaan dan keadaan tua.

\section{Metode}

Desain penelitian ini merupakan studi potong lintang. Penelitian dilakukan di FTb Universitas Atma Jaya dan FK Universitas Atma Jaya. Penelitian dimulai pada bulan Januari hingga Mei 2013. Data penelitian dikumpulkan melalui alat ukur dalam bentuk kuesioner. Alat ukur yang digunakan adalah: Facts on Aging Quiz 1 (FAQ $1),{ }^{5}$ the Anxiety about Aging Scale (AAS), ${ }^{6}$ dan the Aging Semantic Differential (ASD). ${ }^{7}$ Data penelitian bersifat analitik bivariat komperatif numerik tidak berpasangan. Lokasi penelitian di FK dan FTb UAJ. Populasi target penelitian ini adalah seluruh mahasiswa di fakultas manapun di Jakarta yang minimal sudah menempuh 1 tahun perkuliahan. Sementara itu, populasi terjangkau merupakan seluruh mahasiswa di FK dan FTb UAJ yang minimal sudah menempuh 1 tahun perkuliahan.

Pengambilan sampel penelitian ini dilakukan dengan metode acak menggunakan tabel acak. Estimasi besarnya sampel dilakukan dengan perhitungan.

Estimasi besar sampel dihitung dengan rumus:

$$
\mathrm{n} 1=\mathrm{n} 2=\frac{\left\{z_{\alpha} \sqrt{2 P Q}+z_{\beta} \sqrt{P 1 Q 1+P 2 Q 2}\right\}^{2}}{(P 1-P 2)^{2}}
$$

Keterangan:

P2 = Proporsi berpengetahuan baik pada kelompok standar sebesar 0,4768

$\mathrm{Q} 2=1-0,4768=0,5232$

$\mathrm{RR}=2$

$\mathrm{P} 1=\mathrm{RR} \times \mathrm{P} 2=2 \times 0,4768=0,9536$

$\mathrm{Q} 1=1-0,9536=0,0464$

$\mathrm{P} 1-\mathrm{P} 2=0,9536-0,4768=0,4768$

$\mathrm{P}=(\mathrm{P} 1+\mathrm{P} 2) / 2=(0,9536 \quad 0,4768) / 2=0,7152$

$\mathrm{Q}=1-\mathrm{P}=1-0,7152=0,2848$

$\mathrm{Z}=1,96$, kesalahan tipe I sebesar $5 \%$

$Z=0,84$, kesalahan tipe II sebesar $20 \%$

Dengan memasukkan nilai tersebut, maka diperoleh:

$$
\begin{aligned}
\mathrm{n} 1=\mathrm{n} 2 & =\frac{\left\{z_{\alpha} \sqrt{2 P Q}+z_{\beta} \sqrt{P 1 Q 1+P 2 Q 2}\right\}^{2}}{(P 1-P 2)^{2}} \\
& =\frac{\{1,96 \sqrt{2 \times 0,7152 \times 0,2848}+0,84 \sqrt{0,9536 \times 0,0464+0,4768 \times 0,5232}\}^{2}}{(0,4768)^{2}} \\
& =12,72(\text { dibulatkan menjadi 13) }
\end{aligned}
$$

Tiga belas (13) sampel adalah jumlah sampel minimum yang akan diperlukan. Jumlah sampel minimum dikalikan tiga, sehingga menjadi 39 orang, dengan kemungkinan drop out $10 \%$, maka jumlah sampel yang diambil dibulatkan menjadi 
Patrick: Pengetahuan dan Perspektif Mahasiswa tentang Penuaan dan Keadaan Tua

Tabel 1 Hasil Data FAQ 1

\begin{tabular}{lcccccc}
\hline & x Rata-rata & SB & Min & Maks & Test Norm. $^{a}$ & $\mathbf{p}^{\mathbf{c}}$ \\
\hline FK & 51,2 & 9,6 & 20 & 72 & $0,150 \mathrm{~b}$ & 0,199 \\
FTb & 53,87 & 9,6 & 28 & 72 & 0,032 & 0,199 \\
\hline
\end{tabular}

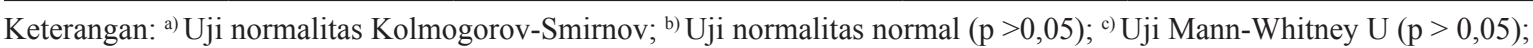
FAQ 1: facts about aging quiz 1; SB: simpangan baku

45 orang. Peneliti akan mengambil jumlah sampel untuk kedua penelitian sebanyak 45 orang untuk masing-masing kelompok sampel (mahasiswa FK dan FTb).

Analisis statistik dilakukan dengan uji-t tidak berpasangan (pada data tidak normal dengan Uji Mann-Whitney U) untuk membandingkan data pengetahuan mengenai proses penuaan dan keadaan tua dari FAQ 1 antara dua jenis sampel. Analisis data perspektif terhadap penuaan dari AAS dan ASD diuji dengan Uji korelatif Pearson (Uji Spearman pada data tidak normal).

Skor AAS memperlihatkan kecenderungan perspektif seseorang terhadap proses penuaan. Responden diminta untuk memilih kecenderungan apakah mereka setuju (1) atau tidak setuju (5) terhadap pernyataan pada kuesioner AAS. Skor AAS merupakan rata-rata dari nilai masingmasing pernyataan.

AAS mempunyai 4 subskala: kekhawatiran terhadap orang tua (fear of old people), fokus pada psikologis terhadap penuaan (psychological concern), penampilan fisik pada penuaan (physical appearance), dan takut akan kehilangan yang berhubungan dengan penuaan (fear of losses).

Skor ASD rata-rata menunjukkan rentang kecenderungan perspektif seseorang terhadap keadaan tua. Responden diminta menyatakan kecenderungan pandangan keadaan tua menurut dirinya (nilai minimal 1 untuk kata sifat positif dan skor 7 untuk kata sifat negatif). Nilai ASD merupakan rata-rata dari skor masing-masing pernyataan pada kuesioner.

ASD memiliki tiga subskala: keefektifan pada saat tua (instrument-ineffective), ketergantungan terhadap orang lain (autonomous-dependent), dan penerimaan diri sendiri (personal acceptance - inacceptance).

\section{Hasil}

Skor maksimum FAQ 1 adalah 100. Skor FAQ 1 kedua kelompok penelitian berada di bawah 60; dapat disimpulkan bahwa mahasiswa FK dan FTb kurang memiliki pengetahuan mengenai penuaan dan keadaan tua. Tabel 1 memperlihatkan tidak terdapat perbedaan pengetahuan yang bermakna antara kedua kelompok kelompok penelitian.

Dari Tabel 2 terlihat skor AAS rata-rata $(\mathrm{FK}=2,61$ dan $\mathrm{FTb}=2,66)$ menunjukkan kedua kelompok penelitian memiliki kecenderungan positif terhadap proses penuaan dan tidak terdapat perbedaan bermakna nilai AAS antara responden FK dan FTb.

Tabel 3 menunjukkan tidak ada perbedaan bermakna pada setiap nilai subskala AAS FK dan FTb.

Melihat rata-rata dari masing-masing subskala AAS dapat disimpulkan responden cenderung tidak takut penuaan, kurangnya memperhatikan keadaan psikologik pada penuaan, juga kurang memperhatikan tampilan fisik dan tidak takut akan kehilangan yang berkaitan dengan penuaan.

Tabel 2 menunjukkan bahwa kedua kelompok penelitian mempunyai kecenderungan positif terhadap keadaan tua (rata-rata $\mathrm{FK}=3,14$ dan $\mathrm{FTb}=3)$.

Tabel 2 Hasil Data AAS dan ASD

\begin{tabular}{lcccccc}
\hline & x Rata-rata & SB & Min & Maks & Test Norm. ${ }^{{ }^{a}}$ & $\mathbf{p}^{\mathbf{c}}$ \\
\hline FK & 2,61 & 0,34 & AAS & & & \\
FTb & 2,66 & 0,35 & 1,9 & 3,55 & 0,02 & $0,238^{\mathrm{c}}$ \\
& & & ASD & & 0,003 & $0,238^{\mathrm{c}}$ \\
FK & 3,14 & 0,61 & 1,29 & 4,1 & $0,2^{\mathrm{b}}$ & $0,06^{\mathrm{d}}$ \\
FTb & 3 & 0,83 & 1,25 & 5,8 & $0,2^{\mathrm{b}}$ & $0,06^{\mathrm{d}}$ \\
\hline
\end{tabular}

Keterangan: a) Uji normalitas Kolgomorov-Smirnov; b) Uji normalitas normal (p > 0,05); $\left.{ }^{\text {c) } U j i ~ M a n n-W h i t n e y ~ U ~(p ~}>0,05\right)$; d) Uji t-dua sampel independen ( $>>0,05)$; AAS: anxiety about aging scale; ASD: aging semantic differential; SB: simpangan baku 
Patrick: Pengetahuan dan Perspektif Mahasiswa tentang Penuaan dan Keadaan Tua

Tabel 3 Hasil Data Subskala AAS

\begin{tabular}{|c|c|c|c|c|c|c|c|c|c|c|c|c|}
\hline & \multicolumn{3}{|c|}{ Fear of Old People } & \multicolumn{3}{|c|}{ Psychological Concern } & \multicolumn{3}{|c|}{ Physical Appearance } & \multicolumn{3}{|c|}{ Fear of Losses } \\
\hline & $\mathbf{x}$ & SB & $\mathbf{p}^{\mathbf{a}}$ & $\mathbf{x}$ & SB & $\mathbf{p}^{\mathbf{a}}$ & $\mathbf{x}$ & SB & $\mathbf{p}^{\mathbf{a}}$ & $\mathbf{x}$ & SB & $\mathbf{p}^{\mathbf{a}}$ \\
\hline FK & 2,7 & 0,51 & 0,21 & 2,25 & 0,46 & 0,8 & 2,6 & 0,57 & 0,92 & 2,91 & 0,73 & 0,47 \\
\hline $\mathrm{FTb}$ & 2,83 & 0,56 & 0,21 & 2,23 & 0,51 & 0,8 & 2,6 & 0,44 & 0,92 & 2,98 & 0,65 & 0,47 \\
\hline
\end{tabular}

Keterangan: ${ }^{\text {a) }}$ Uji Mann-Whitney U (p>0,05); AAS: anxiety about aging scale; $x$ : rata-rata; SB: simpangan baku

Uji-t independen pada Tabel 4 menunjukkan tidak ada perbedaan bermakna pada setiap nilai subskala ASD responden FK dan FTb. Untuk menguji hubungan pengetahuan dengan perspektif penuaan (FAQ 1 - AAS) digunakan Uji Spearman oleh karena hasil uji normalitas menunjukkan distribusi data responden yang tidak normal. Hasil uji menunjukkan tidak ada hubungan bermakna antara pengetahuan dan perspektif penuaan pada kedua kelompok penelitian. Hasil Uji Spearman memperlihatkan konstanta korelasi $\mathrm{FK}=0,088$, sedangkan konstanta korelasi $\mathrm{FTb}=-0,085$.

Untuk dapat menguji hubungan pengetahuan dengan perspektif keadaan tua (FAQ 1-ASD) digunakan Uji Pearson karena hasil uji normalitas menunjukkan distribusi data responden normal. Hasil uji menunjukkan tidak terdapat hubungan bermakna pengetahuan dengan perspektif tentang keadaan tua pada kedua kelompok penelitian. Hasil Uji Pearson memperlihatkan konstanta korelasi FK sebesar -0,125, sedangkan konstanta korelasi FTb sebesar -0,289.

\section{Pembahasan}

Hipotesis awal menyatakan bahwa pengetahuan mengenai penuaan dan keadaan tua mahasiswa FK akan lebih baik bila dibandingkan dengan mahasiswa $\mathrm{FTb}$. Berdasarkan hasil penelitian, nilai FAQ 1 mahasiswa FK dengan FTb UAJ tidak berbeda yang bermakna sehingga hipotesis tersebut ditolak.

Hal yang dapat menyebabkan tidak terdapat perbedaan pengetahuan dalam penelitian ini adalah dasar pengetahuan yang sama antara mahasiswa FK dan FTb yaitu ilmu pengetahuan alam (IPA) di tingkat Sekolah Menengah Atas (SMA). Kurikulum IPA berfokus pada aspek biologi secara umum, tidak menekankan pada aspek ekonomis serta psikologis pada saat tua serta materi mengenai penuaan dan keadaan tua tidak dipelajari secara mendalam. Sementara itu, dalam penelitian Anderson dan Wiscott ${ }^{8}$ di Pennsylvania, mahasiswa nonsosial mempunyai pengetahuan mengenai penuaan dan keadaan tua yang lebih baik dibandingkan dengan mahasiswa sosial.

Menurut penelitian Rosencranz dan McNevin, ${ }^{8}$ perspektif terhadap keadaan tua mahasiswa FK dan FTb termasuk kategori baik. Uji-t independen menunjukkan tidak ada perbedaan yang bermakna nilai ASD responden antara kelompok FK dan FTb. Dilihat dari rata-rata yang didapat pada masing-masing subskala dapat diambil simpulan responden cenderung memandang pada saat tua seseorang akan lebih berguna, tidak bergantung pada orang lain dan dapat menerima keadaannya.

Hasil FAQ 1 dalam penelitian ini menunjukkan rata-rata lebih kecil dari 60. Menurut Palmore, ${ }^{5}$ nilai ini merujuk pada kurangnya pengetahuan mengenai penuaan dan keadaan tua. Penelitian Allan dan Johnson ${ }^{4}$ pada mahasiswa Universitas Canadian jurusan seni, ilmu pengetahuan, dan psikologi memberi rata-rata 47,68. Allan dan Johnson $^{4}$ menyatakan pengetahuan mahasiswa terhadap penuaan dan juga keadaan tua tergolong rendah. Hal ini berbeda dengan penelitian lain yang respondennya adalah perawat profesional dengan minat dalam gerontologi, memiliki ratarata lebih besar dari 60 dan digolongkan sebagai berpengetahuan baik mengenai penuaan ataupun keadaan tua. ${ }^{9}$ Besar kecilnya nilai FAQ 1 dapat dipengaruhi beberapa faktor seperti minat pada

Tabel 4 Hasil Data Subskala ASD

\begin{tabular}{lcccccccccc}
\hline & \multicolumn{3}{c}{ Instrument - Ineffective } & \multicolumn{3}{c}{ Autonomous - Dependent } & \multicolumn{3}{c}{$\begin{array}{c}\text { Personal Acceptance - } \\
\text { Inacceptance }\end{array}$} \\
\cline { 2 - 11 } & $\mathbf{x}$ & SB & $\mathbf{p}^{\mathbf{a}}$ & $\mathbf{x}$ & $\mathbf{S B}$ & $\mathbf{p}^{\mathbf{a}}$ & $\mathbf{x}$ & $\mathbf{S B}$ & $\mathbf{p}^{\mathbf{a}}$ & 0,21 \\
$\mathrm{nyK}$ & 3,41 & 0,72 & 0,76 & 3,15 & 0,65 & 0,19 & 2,97 & 0,69 & 0,21 \\
$\mathrm{FTb}$ & 3,46 & 0,87 & 0,76 & 2,93 & 0,95 & 0,19 & 2,75 & 0,89 & 0,21 \\
\hline
\end{tabular}

Keterangan: ${ }^{\text {a) }}$ Uji-t-dua sampel independen ( $\left.>>0,05\right)$; ASD: aging semantic differential; $x$ : rata-rata; SB: simpangan baku 
Patrick: Pengetahuan dan Perspektif Mahasiswa tentang Penuaan dan Keadaan Tua

Tabel 5 Nilai Subskala AAS Rata-rata

\begin{tabular}{lcccc}
\hline \multicolumn{1}{c}{ Kelompok } & $\begin{array}{c}\text { Fear of Old } \\
\text { Peoplea }\end{array}$ & $\begin{array}{c}\text { Psychlogical } \\
\text { Concerna }\end{array}$ & $\begin{array}{c}\text { Physical } \\
\text { Appearancea }\end{array}$ & Fear of Lossesa \\
\hline FK & $2,7(0,51)$ & $2,25(0,46)$ & $2,6(0,57)$ & $2,91(0,73)$ \\
FTb & $2,83(0,56)$ & $2,23(0,51)$ & $2,6(0,44)$ & $2,98(0,65)$ \\
McConatha dkk. ${ }^{11}$ & $2,19(0,83)$ & $2,19(0,74)$ & $2,35(0,87)$ & $2,75(0,84)$ \\
(Turki) & & & & $2,66(0,69)$ \\
McConatha dkk. ${ }^{11}$ (AS) & $2,09(0,71)$ & $1,97(0,60)$ & $2,51(0,77)$ & \\
a) AAS (SD) rata-rata & & &
\end{tabular}

bidang gerontologi, pendalaman materi mengenai penuaan dan keadaan tua, serta interaksi dengan para lansia.

Minat yang kecil dalam bidang gerontologi mengakibatkan pengetahuan mengenai penuaan dan keadaan tua kurang baik. Beberapa peneliti menyimpulkan seseorang yang tidak berminat di bidang gerontologi memiliki pengetahuan yang kurang mengenai penuaan dan keadaan tua yang diikuti dengan perspektif yang netral terhadap penuaan dan keadaan tua.

Pendalaman materi penuaan dan keadaan tua dapat memengaruhi tingkat pengetahuan tentang penuaan dan juga keadaan tua. Lee dan Waites ${ }^{9}$ menunjukkan bahwa mahasiswa yang mendapat pendalaman materi tentang penuaan dan keadaan tua dalam bentuk berbagi pengalaman, mengalami peningkatan pengetahuan sekaligus perspektif terhadap penuaan dan keadaan tua.

Interaksi dengan para lansia juga memberikan pengaruh pada pengetahuan mengenai penuaan dan keadaan tua. Beberapa peneliti menunjukkan seseorang yang berinteraksi langsung dengan lansia memiliki pengetahuan mengenai penuaan dan keadaan tua yang tergolong baik.

Upaya tersebut dapat diwujudkan dengan cara melakukan kunjungan dan juga pelayanan sosial kepada lansia di panti wreda atau tempat perawatan lansia lainnya, serta pemberian evaluasi mengenai proses penuaan dan keadaan tua pada peserta dengan tujuan peserta mengerti mengenai proses penuaan dan keadaan tua dengan baik.
Hasil AAS mahasiswa FK dan FTb tidak menunjukkan perbedaan yang bermakna. Nilai AAS rata-rata dalam penelitian ini lebih kecil dari garis tengah AAS (3). Menurut Lasher dan Faulkender, ${ }^{6}$ semakin kecil rata-ratanya, semakin positif perspektifnya terhadap penuaan, termasuk di antaranya kekhawatiran terhadap orang tua, fokus psikologis terhadap penuaan dan keadaan fisik pada penuaan serta takut akan kehilangan yang berhubungan dengan penuaan. McConatha dkk. ${ }^{10}$ melakukan penelitian pada mahasiswa Turki dan AS dan mendapatkan nilai rata-rata: fear of old people $(2,14)$; psychological concern $(2,09)$; physical appearance $(2,43)$; dan fear of losses $(2,71)$. Skor rata-rata yang didapat pada penelitian ini tidak jauh berbeda dengan penelitian McConatha dkk. ${ }^{10}$ Kedua penelitian menyimpulkan responden yang seluruhnya adalah mahasiswa memiliki perhatian terhadap penuaan yang cenderung ke arah yang lebih positif.

Pada subskala fear of old people, kelompok McConatha dkk. ${ }^{10}$ di AS memiliki nilai rata-rata yang paling rendah yaitu 2,09 dibandingkan dengan kelompok yang lainnya. Mahasiswa di AS memiliki pandangan yang lebih positif terhadap orang tua dan cenderung tidak takut pada orang tua. Lebih tingginya rata-rata subskala pada penelitian ini dapat disebabkan oleh karena orang Asia cenderung lebih menghormati orang tua. Sung dan Dunkle ${ }^{11}$ menyimpulkan orang timur memiliki nilai kuat terhadap keluarga, terdapat hierarki dalam keluarga tersebut dan rasa hormat

Tabel 6 Nilai Subskala ASD Rata-rata

\begin{tabular}{lccc}
\hline \multicolumn{1}{c}{ Kelompok } & Instrument-Ineffective & Autonomous-Dependent & $\begin{array}{c}\text { Personal Acceptance- } \\
\text { Inacceptance }\end{array}$ \\
\hline FK & 3,41 & 3,15 & 2,97 \\
FTb & 3,46 & 2,93 & 2,75 \\
Rosencranz dan Me Nevin & & 3,32 & 2,81 \\
(AS) & 2,12 & & \\
McConatha dkk. ${ }^{11}$ (AS) & $2,09(0,71)$ & $1,97(0,60)$ & $2,51(0,77)$ \\
\hline
\end{tabular}

Keterangan: FK: Fakultas Kedokteran; FTb: Fakultas Teknobiologi 
kepada yang lebih tua dibandingkan dengan orang barat yang cenderung individualis dan menikmati masa muda. Sung ${ }^{12}$ juga menyatakan bahwa orang Korea yang mewakili kelompok Asia, sejak kecil sudah ditanamkan untuk menghormati dan menjaga orang tua bila dibandingkan dengan pemuda di negara AS. Pada subskala psychological concern, dapat dilihat bahwa AAS rata-rata pada kelompok McConatha dkk. ${ }^{10}$ di AS memiliki ratarata yang paling rendah yaitu 1,97 dibandingkan dengan kelompok yang lainnya. Mahasiswa di AS dianggap memiliki perspektif tentang aspek psikologis penuaan yang lebih positif. Boduroglu dkk. ${ }^{13}$ dan kelompok penelitiannya menunjukkan bahwa konsep psikologis orang Asia berfokus pada tanggung jawab dan bagaimana kelakuannya memberikan efek terhadap orang lain, sedangkan konsep psikologis orang barat berfokus pada diri sendiri. Pada subscale physical appearance, rata-rata AAS pada kelompok McConatha dkk. ${ }^{10}$ di Turki bernilai paling rendah (2,35). Hal ini berbeda dengan hasil dari subskala AAS yang lain. McConatha dkk. ${ }^{10}$ berpendapat kelompok di Turki tampaknya cukup puas akan diri dan kehidupannya. Perbedaan angka pada masingmasing kelompok tidak terpaut jauh. Hal ini terjadi karena baik orang timur dan barat cukup memperhatikan keadaan fisiknya sejak usia dini, sehingga selama proses penuaan kedua kelompok tersebut tidak terlalu mengkhawatirkan keadaan fisiknya.

Rasa takut akan kehilangan yang berhubungan dengan penuaan seperti kehilangan perhatian, kehilangan kesenangan pada saat muda dan kehilangan kerabat dialami secara umum oleh semua kelompok. Pada subscale fear of losses (Tabel 5), dapat dilihat AAS rata-rata hasil penelitian ini paling tinggi. Hal ini terjadi karena orang Asia memiliki keterikatan dengan kerabat yang kuat.

Hasil ASD mahasiswa FK dan FTb tidak menunjukkan perbedaan bermakna. Rata-rata FK dan FTb memiliki angka yang lebih kecil dari garis tengah ASD (4). Menurut Rosencranz dan Mc Nevin, ${ }^{7}$ semakin kecil rata-ratanya menunjukkan seseorang memiliki perspektif yang lebih baik terhadap keadaan tua, termasuk di antaranya efektivitas pada saat tua, ketergantungan pada orang lain, dan penerimaan diri sendiri. Secara keseluruhan penelitian menyimpulkan responden memiliki perspektif yang cukup baik terhadap keadaan tua

Subskala tentang instrument-ineffective pada penelitian ini memiliki nilai rata-rata lebih kecil dibandingkan dengan penelitian Rosencranz dan Mc Nevin ${ }^{7}$ (Tabel 6). Hal ini menunjukkan bahwa orang barat cenderung mempunyai perspektif pada saat tua mereka akan lebih efektif dalam melakukan kegiatan dibandingkan dengan orang Asia. Pada subskala autonomous-dependent, nilai rata-rata dari semua kelompok tidak berbeda jauh. Hal ini menunjukkan baik orang timur maupun orang barat cenderung yakin pada saat tua nanti mereka akan mandiri.

Subskala personal acceptance-inacceptance, nilai rata-rata pada semua kelompok juga tidak berbeda jauh. Hal ini menunjukkan baik orang timur maupun orang barat cenderung memiliki perspektifbahwa mereka dapat menerima keadaan tuanya. Pembentukan perspektif dipengaruhi oleh beberapa faktor seperti suku bangsa, budaya yang dipegang sejak dini, faktor psikologis serta pengetahuan mengenai penuaan dan keadaan tua. Faktor suku bangsa dan budaya yang sudah ada turun temurun mungkin sulit diubah sebagai upaya pembentukan perspektif terhadap penuaan dan keadaan tua. Faktor psikologis dapat berkembang bergantung pada lingkungan sekitarnya, sehingga cukup sulit dalam memberikan intervensi. Faktor pengetahuan mengenai penuaan dan keadaan tua yang sering kali dikorelasikan dengan perspektif terhadap penuaan dan keadaan tua, hal ini dapat diintervensi dengan cara peningkatan pemahaman terhadap penuaan dan keadaan tua.

Dalam penelitian ini tidak ditemukan korelasi pengetahuan dengan perspektif terhadap penuaan dan keadaan tua. Hal ini berbeda dari penelitianpenelitian sebelumnya yang mempunyai nilai FAQ 1 yang cukup tinggi. Dalam penelitian ini, responden memiliki pengetahuan yang kurang dan sebaran hasil kuesionernya tidak mengikuti distribusi normal. Pada penelitian Cottle dan Glover $^{14}$ serta Funderburk dkk. ${ }^{15}$ para peneliti melihat kecenderungan penelitian dengan hasil pengetahuan mengenai penuaan dan keadaan tua yang kurang baik tidak akan memberikan korelasi dengan perspektif terhadap penuaan dan keadaan tua.

Keterbatasan penelitian ini yaitu sampel yang ternyata mempunyai latar belakang cukup homogen. Mahasiswa FK dan juga FTb berasal dari siswa SMA jurusan IPA, sehingga sangat mungkin pengetahuan dasar mengenai penuaan dan keadaan tua tidak terlalu mendalam. Saran untuk penelitian selanjutnya yaitu diperlukan pengambilan responden yang mempunyai latar pendidikan yang cukup beraneka ragam untuk dibandingkan dengan tingkat pengetahuan dan korelasinya terhadap perspektif akan penuaan dan keadaan tua. Dalam penelitian selanjutnya, perlu dilakukan pembagian responden menjadi kelompok-kelompok yang berbeda, berdasarkan tingkat pengetahuan yang diukur dengan FAQ 1. Selanjutnya, kelompok-kelompok ini dapat diteliti korelasinya terhadap perspektif mengenai penuaan dan keadaan tua. 
Berdasarkan analisis di atas, disarankan agar mahasiswa FK mendapatkan kurikulum wajib mengenai penuaan dan keadaan tua, sehingga pengetahuan mengenai penuaan dan keadaan tua meningkat. Demikian pula pada mahasiswa $\mathrm{FTb}$, perlu ditingkatkan pengetahuannya dengan mengadakan seminar maupun materi tambahan mengenai penuaan dan keadaan tua. Diharapkan dengan peningkatan pengetahuan maka perspektif terhadap penuaan dan keadaan tua juga akan baik, sehingga dapat bermanfaat dalam praktik seharihari.

Simpulan, pengetahuan mengenai penuaan dan keadaan tua mahasiswa FK dan FTb masih kurang, perspektif mahasiswa FK serta FTB terhadap penuaan dan keadaan tua tergolong cukup baik. Tidak ditemukan hubungan pengetahuan dengan perspektif terhadap penuaan dan keadaan tua.

\section{Ucapan Terima Kasih}

Kami mengucapkan terima kasih kepada seluruh responden mahasiswa Fakultas Kedokteran dan Fakultas Teknobiologi yang terlibat dalam penelitian ini. Penelitian ini telah lolos tinjauan etik oleh Komisi Etik FKUAJ. Dana penelitian dari Universitas Katolik Indonesia Atma Jaya.

\section{Daftar Pustaka}

1. Population Division of the Department of Economic and Social Affairs of the United Nations Secretariat [Internet]. UN: world population prospects: the 2008 revision population; [date unknown] [diunduh $19 \mathrm{Mei}$ 2012]. Tersedia dari: http://esa.un.org/unpp

2. Badan Pusat Statistik [Internet]. Indonesia: Penduduk menurut kelompok umur, daerah perkotaan/pedesaan, dan jenis kelamin; 2010 [diunduh 30 April 2012]. Tersedia dari: http://sp2010.bps.go.id/index.php/site/ tabel?tid $=263 \&$ wid $=0$

3. Badan Perencanaan Pembangunan Nasional, BPS and UNFPA. Indonesian population projection 2000-2025. Jakarta: Badan Perencanaan Pembangunan Nasional, BPS and UNFPA; 2005.

4. Allan LJ, Johnson JA. Undergraduate attitudes toward the elderly: the role of knowledge, contact and aging anxiety. Educ Gerontol.2009;35:1-14.

5. Palmore FB. Fact on aging: a short quiz. Geronlogist. 1977; 17:315-37.

6. Lasher KP, Faulkender PJ. Measurement of aging anxiety: development of the anxiety about aging scale. Int J Aging Hum Dev. 1993;37(4):247-60.

7. Rosencranz HA, McNevin TE. A factor analysis of attitudes toward the aged. Gerontologist. 1969;9:55-9.

8. Anderson A, Wiscott R. Comparing social work and non-social work students' attitudes about aging. J Gerontol Soc Work. 2008:47(2):173-86.

9. Lee EKO, Waites CE. Infusing aging content across the curriculum: innovations in baccalaureate social work education. J Soc Work Educ. 2006;42(1):49-66.

10. McConatha JT, Hayta V, Rieser-Danner L, McConatha D. Turkish and U.S. attitudes toward aging. Educ Gerontol. 2004;30(3):169-83.

11. Sung KT, Dunkle R. Roots of elder respect: ideals and practices in East Asia. J Aging Humanit Arts. 2009;3(1):6-24.

12. Sung K. Elder respect among young adults: a cross-cultural study of Americans and Koreans. J Aging Stud. 2004;18:215-30.

13. Boduroglu A, Yoon C, Luo T, Park DC. Agerelated stereotypes: a comparison of American and Chinese cultures. Gerontologist. 2006; 52(5):324-33.

14. Cottle NR, Glover RJ. Combating ageism: change in studentknowledge and attitudes regarding aging. Educ Gerontol. 2007;33:501-12.

15. Funderburk B, Damron-Rodriguez J, Storms LL, Solomon DH. Endurance of undergraduate attitudes toward older adults. Educ Gerontol. 2006;32:447-62. 